\title{
University Library Branches Abroad
}

\author{
By ELIZABETH D. CONFER
}

$I^{N}$ N Colonial times American college libraries depended largely upon a flow of books from Europe. Many of their shelves were filled with volumes brought back by professors who had studied abroad or were donated by benefactors who had traveled in the old continent. While colonial librarians may have anticipated that a current in the opposite direction would be stimulated when European libraries began to find it worth while to acquire books published in the New World, it is unlikely that they foresaw that American college library resources for actual use by American students in American reading rooms would eventually cross the Atlantic. This has happened now on a small but mounting scale. It takes the form of the library of a university branch abroad, and it poses for the parent university library some new and not easily solvable problems in respect to the acquisition, service, and protection of overseas collections.

These libraries are part of instructional branches that American universities have begun to set up in other lands during the last five years. Formerly there were only two choices open to students who sought some kind of formal study outside of their country: to enroll in a foreign university, or to join one of the junior-year-abroad programs offered by a number of American colleges and universities. Both alternatives demanded a greater previous knowledge of a foreign language than most students possessed. The new program, giving instruction in English except for the required language course, offers an opportunity to larger numbers if they want four to six months of experience in a foreign country and
Mrs. Confer is Bibliographer, Syracuse University Library. She served as library consultant to the Syracuse-Semester-in-Italy in 1959-60.

are willing to learn, after arrival, the language of the country of their choice. It provides fully recognized American course credit without interruption of normal academic progress toward an American degree.

This trend toward the branch abroad has begun to attract serious surveys and evaluations. John Garrety and Walter Adams, in their From Main Street to the Left Bank, 1 recognize the problem of having books available for students receiving instruction in English. But they mention it only in terms of the use of an already-established foreign university library. This article is concerned with the idea of a new American university library overseas which supplements a curriculum approximating that which the student would have taken on the home campus (with emphasis, of course, upon the culture and history of the native locale).

The author was library consultant to the Syracuse Semester-in-Italy from May 1959 until the end of June 1960. The last four months of the period were spent in Florence at the scene of the operation. Later a visit was made to the library of the Stanford branch at Beutelsbach near Stuttgart, the only Stanford branch which had been opened at that time. Since then, Stanford has established branches in Tours, France, and Fiesole,

1 John Garrety and Walter Adams, From Main Street to the Left Bank (East Lansing, Mich.: Michigan State University Press, 1959). 
Italy. Syracuse now has a branch in Guatamala as well.

Most new and experimental academic programs are conducted within a narrow budget. The overseas branch is no exception. Furthermore, it is affected by the necessarily small scale of the enterprise. Enrollments are usually restricted to under a hundred students by such factors as housing problems, limited course offerings, and the somewhat greater financial burden to be borne by the student or his parents. For the overseas library this means that the collection will probably begin with only three or four hundred books, comprising general reference works and the four or five subject fields in which courses will be taught. In most cases, this is perhaps too small a collection to be considered a branch of the main library in the customary oncampus sense. In most cases also, the budget of the overseas project will not allow the employment of a full-time trained librarian in the foreign center. This may leave the library something of an orphan. Its books will probably be purchased out of the budget of the overseas branch, not from the general library budget. And it probably will have access only occasionally to professional advice and on-the-spot supervision.

\section{Book SELEction}

The book selection in the four subjects offered by the Syracuse Semester-inItaly (fine arts, history, Italian, and political science) was made by the professor teaching each course and the director of the program. A few books for leisure reading were chosen; some of these were purchased and some were duplicate copies from the home library. The presence in Florence of two libraries with books in English-the British Institute and the USIS library-influenced the selection of reference materials. Since the students would have access to these established collections, the Syracuse branch refer- ence collection did not need to be as extensive as the one at the Stanford branch at Beutelsbach, which is a number of miles from a large city. But it did include Webster's New International Dictionary and Spinelli's Dizionario Italiano e Inglese $e$ Viceversa; The Columbia Encyclopedia and The Encyclopaedia of the Social Sciences; The World Almanac and The Statesman's Yearbook; and Muir's Historical Atlas. The British Institute was also a helpful source for additional books needed for the study of all the subjects except Italian. While American students could use the USIS library free of charge, a modest group fee was required by the British Institute. Both libraries offered good periodical collections from their respective countries. The Syracuse-in-Italy library placed subscriptions for two Italian newspapers, $L a$ Stampa and Il Tempo; the European edition of the Sunday New York Times, Le Monde, and the Manchester Guardian Weekly; Il Ponte, an Italian quarterly published in Florence, and The Italian Quarterly (Berkeley).

The bulk of the new collection (about three hundred titles) was purchased in the United States, gathered in one place, and sent in the ship which took the first group of thirty students (now grown to sixty) and the faculty to Italy in August 1959. In many instances paperback editions were chosen to save money in purchase and shipping costs. More recently additional acquisitions have been made with books bought in Florence or ordered from England and the United States. A few gifts from people interested in the program have come in.

The materials selected for reading in the courses given in history and political science ranged from the Middle Ages to the present in time and over Western Europe and Great Britain in scope. Since special emphasis was given to Italy and to Florence, some of the books pertaining to those areas may be noted. For history and culture in the Renaissance there 
were Cecilia Ady, Lorenzo de Medici and Renaissance Italy; Harold Acton, The Last of the Medici; Hans Baron, $\mathrm{Hu}$ manistic and Political Literature in Florence and Venice at the Beginning of the Quattrocento; Federico Chabod, Machiavelli and the Renaissance; David Herlihy, Pisa in the Early Renaissance; Garrett Mattingly, Renaissance Diplomacy; and Pius II, Memoirs of a Renaissance Pope (new edition). For the nineteenth and twentieth centuries some of the titles were Gaetano Salvemini, Mazzini; Denis Mack Smith, Cavour and Garibaldi; by the same author, Italy, a Modern History; A. C. Jemolo, Church and State in Italy, 1850-1950; and Norman Kogan, Italy and the Allies.

The classics in paperback editions included Boccaccio, Decameron; Cellini, Autobiography; Burckhardt, The Civilization of the Renaissance; Machiavelli, The Prince and the Discourses; The Portable Dante; and Vasari, Lives of the Painters. Background material for visits to churches and galleries of Florence and other cities was provided by Bernard Berenson, Italian Painters of the Renaissance; Millard Meiss, Painting in Florence and Siena after the Black Death; Nikolaus Pevsner, Outline of European Architecture; Jules Struppeck, The Creation of Sculpture; and Wylie Sypher, Four Stages of the Renaissance.

Among the titles selected for an understanding of political and social conditions in Italy today could be found Edward Banfield, The Moral Basis of a Backward Society; Robert Dickinson, Population Problems of Southern Italy; Danilo Dolci, To Feed the Hungry: Report from Palermo; The Presidency of the (Italian) Council, Ten Years of Italian Democracy, 1947-1957; and Elizabeth Wiskmann, Italy.

The problem created by a limited budget becomes most obvious in the administration of the overseas library. With no professional librarian or even a nonprofessional adult in charge, it may be handled in either of two ways. On a formal basis, paid student assistants may administer a library operating for certain hours in a designated reading room and establishing loan periods, fines, and certain other regulations. On an informal basis, a collection of books may be placed on the shelves in a classroom or lounge with no one in charge and the students permitted to borrow them as they please. When it became apparent that during the first semester of Syracuse-in-Italy all library duties would be performed by student assistants, following directives sent with the books, it was decided that the library must be set up according to a simple classification. The books for each subject field were to be arranged on the shelves alphabetically by author. An author-title catalog and a shelf list were prepared and sent, although with so small a collection the tendency is for the students to go to the shelves and look rather than consult a catalog. The books were cataloged and provided with book cards.

\section{STUdENTs "SET UP ShOP"}

Immediately after their arrival in Florence the four student assistants (one of them had had previous library experience and so was "in charge") unpacked the books and placed them on shelves in a pleasant room designated as the library in the villa rented by Syracuse University. A certain section was set aside for reserve books wanted by professors for special use. The student staff was ready then to handle circulation and to see that the simple rules were followed. That they found it difficult to collect fines from their friends seems to have been the principal criticism of their work. Perhaps the small size of the student body engendered more esprit de corps and a greater sense of responsibility than is frequently shown by students on the home campus, for when an inventory was taken at the beginning of the spring semester the collection was intact. 
On the whole, these budding libraries have served their programs well. Probably some of their success can be attributed to the enthusiasm of students and faculty who sensed that they were engaged in a pioneering venture. This momentum may be no guarantee of efficiency in the future, particularly if foreign branches take permanent root in American academic life and their enrollments expand. Opponents of the branch abroad idea are alert for any signs of academic inadequacy, and the quality of the library properly becomes one of the tests.

Distance is not alone the danger. More serious is the looseness of the tie between the overseas library and the parent library. Since later acquisitions are ordered from a separate budget, the main library has little notion of changes going on in the overseas collection. It is possible for the parent library to have no accurate conception of holdings unless the university branch should fail and close its doors, presumably leaving the collec- tion to be returned to the United States. Just as the home library should not be allowed to remain in the dark about the overseas collection, so the library abroad will in the long run need to profit from the professional experience of the home library. When overseas university branches achieve permanence and economic security, untrained student assistants will have to be supplemented with adult personnel capable of managing growing collections. How can these two interests, separated by thousands of miles, be brought together? Since the need for librarians trained in foreign languages and cultures continues to grow, library schools might be willing to consider the university branch system as a training ground for a certain number of their students. While continuing their course work in academic subjects, library students would have the inestimable benefit of language preparation in a foreign country, as well as the opportunity to observe some great public and private libraries abroad in action.

\section{Library 21 Project}

$\mathrm{T}$ HE LAST time that ALA participated in a world's fair was at San Francisco, in 1915. At that fair, seventy-five square feet of floor space was devoted to the display of books by ALA. One of the exhibit's distinguished visitors was Teddy Roosevelt, who, after spending about an hour browsing, uttered a very satisfied "bully" to Joseph Wheeler, the librarian.

Forty-seven years later, an automated Library of the Future occupies nine thousand square feet of floor space, and features electronic machines employing the latest techniques in storage and retrieval of information, book browsing areas, and a unique children's library, at the Seattle World's Fair, April 21October 21, 1962.

Library 21 was stimulated by a grant from the Ford Foundation's Council on

Library Resources and a grant from the U. S. Office of Education. Joseph Becker of Washington, D. C., is co-ordinator, and Gordon Martin, assistant university librarian at the University of California, Riverside, is local project director. Irving Lieberman, director, School of Librarianship, University of Washington, is chairman of the ALA Advisory Committee.

Two ACRL committees are working with exhibitors: a committee of the Rare Books Section of ACRL, under the chairmanship of Mrs. Frances J. Brewer, chief, rare books division, Detroit Public Library, is working with Radio Corporation of America; and a second committee, under the chairmanship of Lawrence Clark Powell, director, School of Library Service, University of California, Los Angeles, is advising IBM. 